\title{
CARBON DIOXIDE ACCUMULATION VALVE LEAKS AND INADEQUATE ABSORPTION ${ }^{1,2}$
}

\author{
James H Kerr, M B, and Johr L Evers, Ph D ${ }^{3}$
}

In the types of breathing curcuts commonly used in general anaesthesia, valves are utlized to provide etther unidrectional gas flow or a pressure release (popoff) In the closed circle, satsfactory function is dependent upon the untegrity of the valves, the occurrence of a defect allows reflux and an opportunity for rebreathing In practice, two types of valve are in use to provide the undurectional flow in the closed crrcle, the gravity-returned rigid disc and the rubber or plastic mushroom The former type has been observed to become fixed in the open position during use, although more common at the expratory valve, where condensation of water vapour from the pataent's exhaled gases occurs, stickng has also been noted at the inspuratory side The mushroom type of valve may become "Aluted," wherein one segment of the valve protrudes through the supporting grid and is retamed thereby, such an occurrence is usually the result of exposure to elevated back pressures as occurs when one forcibly breathes aganst a single valve

It is prumarily with the effect of leaks in these valves, expressed in terms of carbon dioxide rebreathed, that this presentation is concerned However, as adequate carbon droxide absorption is also of prime importance in the closed curcle system, some observations are offered on the use of canisters, both in this and the to-and-fro system

\section{Procedure and Equipment}

The procedure was designed to demonstrate the effect of valve leak or insuffcient carbon dioxide absorption, at the same tume takng into account the physiological response obtamed from an unmedrcated patient

An Oho 19-type crrcle and absorber was utllized for observations on its own built-m valves and other substituted valves in differnng arrangements, whth and without deliberately mtroduced leaks which sunulated those which were observed in clinical practice For the to-and-fro system, a standard Waters $(8 \times 13 \mathrm{~cm})$ canster was used

The valves investgated were those built into the Oho 19 canister and both the yoke and indindually mounted valves produced by Anesthesia Associates, Inc

Two Oho 19 canısters were used, one contaned fresh lime, the other had been used untl at was allowing passage of 2 per cent carbon dioxade Simlarly, the Waters camisters contamed fresh and used lime

1Thes study was supported in part by funds provided under Contract DA 49-007-MD-507 whth the Division of Research and Development, Office of the Surgeon General, Department of the Army, U S A.

2Presented at a meeting of the Ontario Division, Canadian Anaesthetsts Society, Hamilton, Ontario, October 5, 1957

BDcpartment of Anaesthesiology, Roswell Park Memonal Instrtute, Buffalo, N Y 
The analysing equipment consisted of a Liston Becker (Model 16) carbon dioxide analyser and a pneumotachograph. The dead space of this analysing equipment and mouthpiece was roughly that of a conventional mask, $110 \mathrm{cc}$. These two instruments, suitably calibrated, enabled us to obtain continuous measurement of flow rates and carbon dioxide concentrations of the respired gases. The signals from the carbon dioxide analyser and from the differential strain gauge attached to the pneumotachograph were amplified and recorded on Sanborn equipment. These two records, carbon dioxide concentration and flow, yield several parameters, including dead space.

Figure 1 illustrates the arrangement of mouthpiece, analysing equipment, and anaesthetic apparatus.

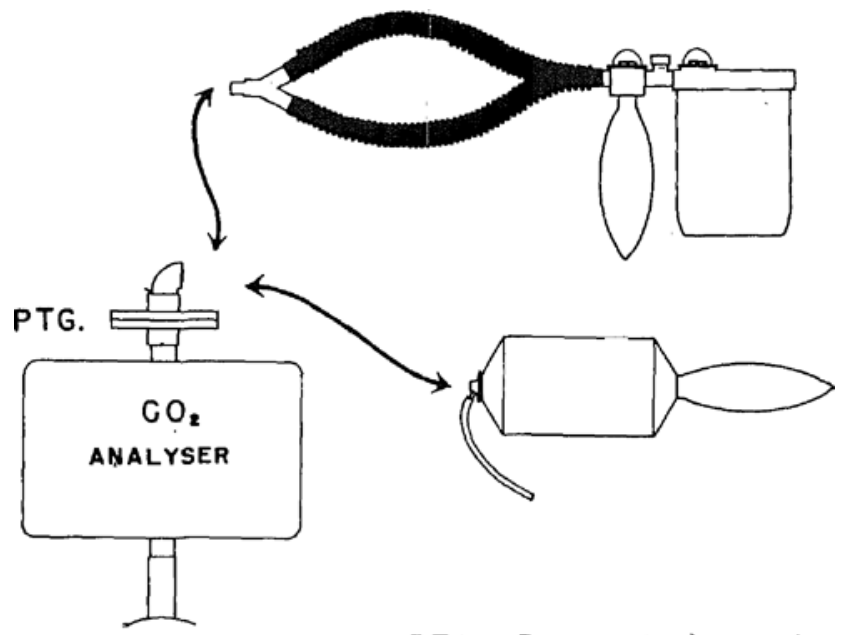

PTG. : Pneumotachograph.

Ficune 1. Illustrating the arrangement of mouthpiece, analysing equipment, and anaesthetic apparatus. The arrows indicate the position of attuchment of the parts during the procedures.

The subject, unmedicated but under basal conditions, was first required to breathe through the analysing equipment until a steady state had been achieved. Thereafter, the various arrangements of anaesthetic apparatus were attached for short periods of time and their immediate effects recorded. Between procedures, a short period of air breathing was allowed during which the apparatus was thoroughly flushed and filled with carbon dioxide-free air. During observations on the closed circle and to-and-fro system, oxygen was added throughout at a rate of $250 \mathrm{cc}$. per minute. The subject had no knowledge / of the particular changes that were being utilized and had been trained by previous experiments to allow his natural respiratory responses to occur without inhibition. 


\section{ResUlts}

The results given in Table I are obtaned from sungle breaths at the time stated after the beginming of each procedure These figures refer solely to the total volumes of gas and carbon droxude content entering and leaving the anaesthetic apparatus, effects of mstrumental dead space are excluded Inspured carbon dioxude concentrations up to 63 per cent are recorded with a corrésponding increase in tudal volume of almost 350 per cent The conditions of the experiments would not allow the development of a steady state and in certain cases the changes were progressing rapidly towards carbon dioxide concentrations which would have caused considerable distress to our sub ect and denred the possibility of continumg with other observations We noted a so that some of the responses appeared anomalous Four of our observations mclude alveolar carbon dioxide concentrations below the value obtained when the patient was breathing ambient air only through the analysing equipment It will be noted that where such lowered alveolar carbon dioxide concentrations occurred, the patient's tidal volume is somewhat elevated On examming the tme interval from the previous procedure, we noted that we had allowed insufficient time for sustaned response to have subsided

$T+B L E I$

1+RESH Lim[1

\begin{tabular}{|c|c|c|c|c|c|c|c|c|c|c|}
\hline $\begin{array}{l}\text { Pro } \\
\text { cedure }\end{array}$ & Circuit & Values & $\begin{array}{l}\text { Alveolar } \\
\text { CD }(\%)\end{array}$ & $\begin{array}{l}\text { Thd 1 } \\
\text { iolump } \\
\text { (cc) }\end{array}$ & $\begin{array}{c}\text { Rate } \\
\text { (breatlus } \\
\text { pet tain) }\end{array}$ & $\begin{array}{l}\text { Tinle } \\
\text { (min) }\end{array}$ & $\begin{array}{l}\text { I aus aleut } \\
\text { added } \\
\text { dend spdee } \\
\text { (cc) }\end{array}$ & $\begin{array}{l}\text { Average } \\
\text { msplfed } \\
\text { CO }(\%)\end{array}$ & $\begin{array}{c}\text { Total CO } \\
\text { ingulred } \\
\text { (ce) }\end{array}$ & $\begin{array}{l}\text { Minimum } \\
\text { msjured } \\
\text { CD }(\%)\end{array}$ \\
\hline 2 & Closed circle & $\begin{array}{c}10 \\
\text { Exp yalue } \\
\text { leak } \\
10\end{array}$ & 61 & 725 & 105 & $=25$ & 170 & $1 t$ & 105 & $\$ 1$ \\
\hline 3 & Closed circle & $\begin{array}{c}\text { Ins balse } \\
\text { leak } \\
\text { 19 }\end{array}$ & 60 & $84+5$ & 120 & 1,1 & $2 H O$ & 14 & 175 & 0 \\
\hline 4 & Closed circle & $\begin{array}{c}\text { Botli leak } \\
A A\end{array}$ & 07 & 455 & 9.5 & 1, & 830 & $5 \mathrm{H}$ & 500 & 38 \\
\hline 5 & Closeci circle & Intact & 51 & 825 & 70 & 175 & 10 & $<01$ & 05 & 00 \\
\hline 6 & Closed curcle & $\begin{array}{c}\text { Ins value } \\
\text { leak } \\
\text { SS }\end{array}$ & B 1 & 755 & 87 & I 3, & 18.5 & 17 & 110 & 00 \\
\hline 18 & Closed circle & $\begin{array}{c}\text { At } \\
\text { canister } \\
\text { SS }\end{array}$ & 14 & 1200 & 75 & 171 & 40 & 02 & 20 & 00 \\
\hline 19 & Closed curcle & At & +9 & $6+10$ & 80 & 05 & I0 & 03 & 20 & \\
\hline 20 & To and fro & & 56 & 790 & 70 & 10 & 40 & 01 & 23 & 00 \\
\hline Alr & & & 58 & $\$ 10$ & 90 & 825 & 0 & 0 & 0 & 00 \\
\hline
\end{tabular}

From the figures obtaned, it is apparent that in closed curcle, or to-and-fro systems, which are functoning correctly, there is only a slght elevation of $\mathrm{m}-$ spured carbon dioxide The introduction of the valvular leak in the circle system produces an immediate ruse in the inspired carbon dioxide level The additive effect of a double valve leak is demonstrated The rapidity with which such levels can be attaned can be seen from the reproductions of specimen recordings in Figure 2. 


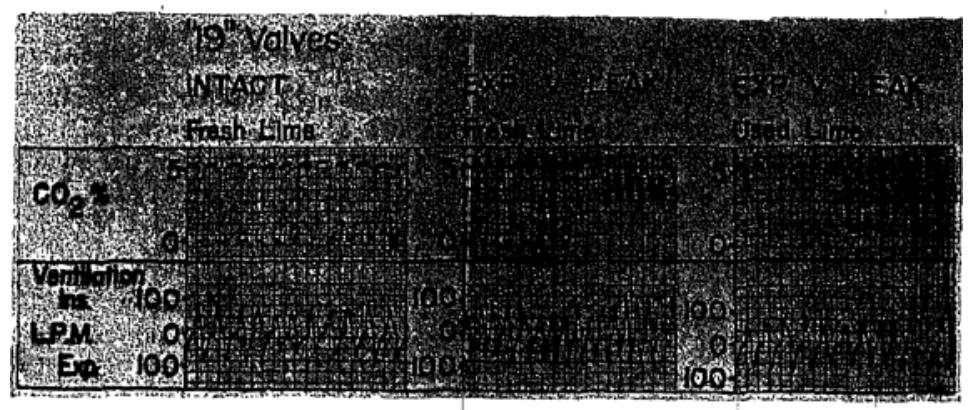

Ficune 2. The rapid rise in the inspired carbon dioxide level inmediately following the attachmont of the anaesthetic apparatus is demonstrated.

\section{Discussion}

The significance of these grossly elevated values for inspired carbon dioxide levels is most dramatically cxpressed in terms of ventilation required to maintain carbon dioxicte homeostasis. The figures given in the table for tidal volume are expressions of the subject's efforts to achieve this goal under the various circumstances. In the absence of the steady sthte, they do nof depict the actual increment

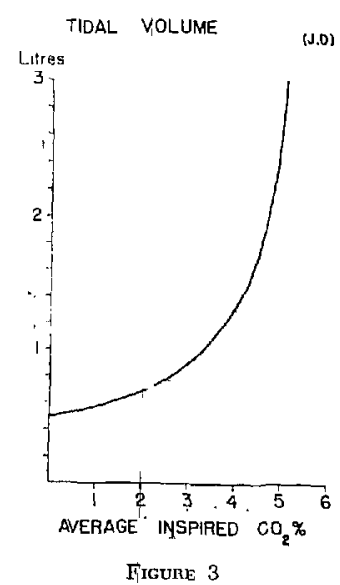

in ventilation necessary to compensate for a particular inspired carbon dioxide level. These relationships are' expressed in the basic equation for pulmonary ventilation for a single breath at fixed frequency (1): 
tidal volume - dead space $=$ alveolar ventilation $=\frac{\mathrm{CO}_{5} \text { production }}{\text { alveolar } \mathrm{CO}_{2} \text { fraction }- \text { inspired } \mathrm{CO}_{2} \text { fraction }}$

The graph (Figure 3) calculated from observations upon his particular subject (arbon dioxide production $192 \mathrm{cc}$. per minute) while kreathing ambient air ilust-ates the alterations in his tidal volume at a rate of nine breaths per minute whic. would be required to achieve homeostasis with various levels of inspired carbon dioxide. To combat some of the levels of inspired carbon dioxide which were found in our procedures (Tables I and II), it can be seen that the ventilation

TABLE II

USED LIME

\begin{tabular}{|c|c|c|c|c|c|c|c|c|c|c|}
\hline $\begin{array}{l}\text { Pro- } \\
\text { cedure }\end{array}$ & Circuit & Valves & $\begin{array}{l}\text { Alveolar } \\
\mathrm{CO}_{2}(\%)\end{array}$ & $\begin{array}{l}\text { Tidal } \\
\text { volume } \\
\text { (cc ) }\end{array}$ & $\begin{array}{l}\text { Rate } \\
\text { (breaths } \\
\text { per min) }\end{array}$ & $\begin{array}{l}\text { Time } \\
(\min )\end{array}$ & $\begin{array}{l}\text { Equivalent } \\
\text { added } \\
\text { dead space } \\
\text { (cc) }\end{array}$ & $\begin{array}{l}\text { Average } \\
\text { insplred } \\
\mathrm{CO}_{2}(\%)\end{array}$ & $\begin{array}{c}\text { Total } \mathrm{CO}_{2} \\
\text { inspired } \\
\text { (cc) }\end{array}$ & $\begin{array}{l}\text { Minimum } \\
\text { inspired } \\
\mathrm{CO}_{2}(\%)\end{array}$ \\
\hline 1 & Closed circle & $\underset{19}{19} \underset{19}{\operatorname{Intact}}$ & 67 & 1280 & 65 & 35 & 335 & 18 & 225 & 15 \\
\hline 2 & Closed circle & $\begin{array}{c}\text { Exp valve } \\
\text { leak } \\
19\end{array}$ & 75 & 1310 & 75 & 35 & 855 & 49 & 645 & 44 \\
\hline 3 & Closed circle & $\begin{array}{c}\text { Ins valve } \\
\text { leak } \\
19\end{array}$ & 64 & 1235 & 75 & 75 & 685 & 36 & 445 & 12 \\
\hline 4 & Closed circle & $\begin{array}{c}\text { Both leak } \\
\text { AA }\end{array}$ & 71 & 1730 & 80 & 55 & 1525 & 63 & 1090 & 47 \\
\hline $\mathbf{5}$ & Closed circle & $\underset{A A}{\text { Intact }}$ & 61 & 680 & 85 & 475 & 155 & 14 & 95 & 10 \\
\hline 6 & Closed crrcle & $\begin{array}{c}\text { Ins value } \\
\text { leak } \\
\text { AA }\end{array}$ & 61 & 915 & 70 & 425 & 390 & 26 & 240 & 05 \\
\hline 7 & Closed circle & Exp valve & 60 & 930 & 75 & 375 & 395 & 25 & 235 & 20 \\
\hline 18 & Closed circle & $\begin{array}{c}\text { At } \\
\text { Canister } \\
S S\end{array}$ & 53 & 1225 & 50 & 325 & 315 & 14 & 175 & 10 \\
\hline 19 & Closed circle & At & 58 & 740 & 80 & 30 & 160 & 13 & 95 & 10 \\
\hline 20 & $\begin{array}{l}\text { To-and-fro } \\
\text { closed }\end{array}$ & $p$ & 58 & 705 & 100 & 525 & 120 & 10 & 70 & 05 \\
\hline
\end{tabular}

VAlves 19 -gravity returned fibre disc type mounted on Ohio 19 canister AA Anesthesia Associates' valves mounted in yoke

SS-Anesthesia Associates' individually mounted valves (Sierra Silicone)

of a very high order is required to prevent carbon dioxide accumulation. As the inspired level of carbon dioxide approaches that of the subject's resting alveolar value, the required ventilation approaches infinity, with even higher values, no amount of effort would obtain homeostasis.

It will be noted that our subject did not manage to maintain his alveolar carbon dioxide at his resting level of 5.8 per cent during many of the procedures (2).

The results of including in the circuit a canister containing expended lime were as expected. The canister used for these observations, as already stated, had been correctly packed and utilized until it was allowing passage of 2 per cent carbon dioxide. At this point, the indicator in the granules on the surface had just begun to change colour which a casual glance would probably not have detected. We know from previous experiments that there is a considerable period between the onset of incomplete carbon dioxide absorption and the appearance of indicator change in the surface granules in this particular canister. Thus, to rely upon inspection of the surface lime is fallacious. Furthermore, there is no means of observing the lime indicator during use. 
In the results obtained during the procedures when the Anesthesia Associates' valves were used instead of the valves on the canister, there are marked differences in the equivalent added dead spaces with the different valve positions. An equivalent added dead space of 10 cc. results with the yoke valves and fresh lime in the canister; it is increased to $40-45 \mathrm{cc}$. when the individually mounted valves are placed at either the patient or canister end of the corrugated tubes of the circle (Procedures 5, 18, 19). The values obtained for equivalent added dead space with used lime in the canister in the same procedures confirm the effects of the different placement of the valves.

Under normal clinical conditions for general anaesthesia, it is not always feasible to obtain contunuous monitoring of respired carbon dioxide. Moreover, as drugs $(3,4)$ and surgical procedures modify the physical signs of carbon dioxide retention, its diagnosis becomes complicated and unreliable. This, in turn, signifies that the detection of elevated levels of inspured carbon dioxide is difficult. If the effect of the drujs and procedures of surgery upon the items in the equation for pulmonary venti ation are considered, the maintenance of carbon dioxide homeostasis is seen to be subject to many variables. Thus, increases in inspired carbon dioxide must be compensated by increases in ventilation commensurate with alterations in the other items concerned. It may be that the conditions of anaesthesia are such that a patient is capable of spontaneously maintaining a steady alveolar carbon dioxide concentration; more often this is not so, and it rests with the anaesthetist to augment the ventilation.

These studies.demonstrate the fallacy of depending on even the most modern equipment and valves to provide reliable carbon dioxide elimination. That such levels of inspured carbon dioxide can occur, and be respired by subjects whose responses are obtunded, provides cause for some consideration.

It would seem opportune, at this point, to observe that where valvular defects occur and provide opportunity for rebreathing, the oxygen concentration will fall as the inspired carbon dioxide rises (5).

\section{Comments}

Although these observations have been performed with particular makes of equipment and valves, similar faults have been noted in other manufactured apparatus. The indictment of valves and soda lime containers is intended for all designs which respectively are subject to develop leaks or provide no simple means of determining adequate carbon dioxide absorption.

\section{SUMMARY}

The effects on an unmedicated subject of valvular leaks and inadequate carbon dioxide absorption in a circle and a to-and-fro system are investigated. The results are expressed in terms of elevated percentages of inspired carbon dioxide, and the increase in ventilation required to maintain carbon dioxide homeostasis in a particular subject is calculated.

Attention is drawn to the dangers of high inspired carbon dioxide levels in general anaesthesia and the necessity for maintaining adequate ventilation. 


\section{ACKNOWLEDGMENTS}

We are grateful to Doctors James O. Elam, Veronica Bakamjian, and Clinton D. Janney of this department for the advice and assistance so freely given in the preparation of the material for this paper.

\section{RÉsumé}

Dans les circuits qu'on emploie courament en anesthésie générale, on place des valves, soit pour donner à l'atmosphère une seule direction, soit pour limiter sa pression. Dans le cas du circuit fermé, pour qu'll fonctionne de façon convenable, il faut que les valves soient étanches. Toute défectuosité entraîne un reflux et permet la respiration de l'air exhalé. Le premier but de ce travail est de montrer les conséquences des défectuosités de ces valves en ne considérant que la quantité de gaz carbonique réinspiré.

D'après les chiffres obtenus au cours de cette étude, ll est manifeste que si les systèmes fonctionnent bien, qu'il s'agisse du circuit fermé ou du "va, et vient," le taux d'élévation du gaz carbonique n'est que très faible Si l'on provoque une défectuosité à une valve du crrcuit, le taux de gaz carbonıque rémspiré s'élève immédiatement. Si la défectuosité est provoquée aux deux valves, les conséquences s'additionnent. La rapidité avec laquelle de hautes teneurs en gaz carbonique peuvent être atteintes est considérable ansı qu'on peut le constater par les graphiques de la figure 2

Dans l'occurrence de taux de gaz carbonique aussi élevés dans le circuit, le volume de ventilation nécessaire pour éviter laugmentation du taux de gaz carbonique dans le sang devient effarant Si l'on intercale dans le curcuit un contenant de chaux efficace, les résultats sont éloquents comme le montrent les tableaux Ces études démontrent l'imprudence sinon l'erreur de compter sur la machine, même la plus moderne, pour assurer l'élimination du gaz carbonique Quand il survient des défectuosités aux valves, 1 l s'ensıit une élévation du taux de gaz carbonique à cause de la réinspiration, et, sı le taux de gaz carbonique augmente, le taux d'oxygène va diminuer

\section{REFERENCES}

1 Comroe, J H, Jr, Forster, Robert E, Dubors, Arthur B, Briscoe, William A, \& Carlsen, El.zZabetr. The Lung, 1st ed Chicago Year Book Publishers (1956)

2 Ciappison, G B., \& Hammton, W. K Respiratory Adjustments to Increases in External Dead Space Anesthesiology 17 (5). 643 (1956).

3 Elam, J O, \& Brown, E S Carbon Dioxide Honneostasis durng Anesthesia IV An Evaluation of the Partal Rebreathing System Anesthesiology 17 (1) 128 (1956)

4. TENney, S. M The Interpretation of Respiratory Drug Effects in Man Anesthesiology 17 (1). 82 (1956).

5. Swartz, C. H., Adrian, J., and Mmr, A Semiclosed Inhalers Studies of Oxygen and Carbon Dioxide Tensions during Various Conditıons of Use Anesthesiology 14(5) 437 (1953). 